\title{
Foreign Direct Investment and Unorganised Retail Sector - A Case Study.
}

\author{
Sameer Ahmad Shalla ${ }^{1}$,Manmeet Singh Mehta ${ }^{2}$ \\ ${ }^{1.2}$ Research Scholar, School Of Business StudiesIslamic University Of Science \& Technology.
}

\begin{abstract}
The study attempts to explore the impact of selected shopping malls on unorganised retail outlets. The results from the sample respondents reveal that the shopping malls have a positive impact on various variables like profits, sales. The unorganised retail outlets were classified on the basis of various factors like demographic, social and infrastructure related factors. Apropos to findings, the study concludes that there is some credible merit in introduction of "FDI in Retail Sector" by the state government of Jammu \& Kashmir.
\end{abstract}

Keywords: Shopping Malls, unorganised retail, sales, profitability.

\section{Introduction}

Indian economy is dominated by agriculture sector on employment front with retail sector enjoying the second place. This is in fact the largest private industry in India and poised to witness a major shift on account of the opening of the retail industry to multi-brand foreign direct investment (FDI). Retail sector in India is anticipated to grow around 25-30\% annually. The contribution of retail industry to GDP of India was between 810 per cent in 2007, and reached the figure of 22 per cent by 2010. The recent decision by Government of India to allow 100 per cent FDI in multi-brand retail has generated a lot of interest amongst all the stake holders on the likely impact of this decision. Albeit, the Govt. of India has been relentlessly advocating FDI in multi-brand retail primarily because of its impact on bolstering the farmers' incomes, both upstream and downstream infrastructure development, and remunerative prices for farmers, tame inflation and sophisticated technical and managerial skill transfer.

The gigantic retail stalwarts from abroad like Wal-Mart, Carrefour etc. with their huge capital base and Technical know, unorganised retail outlets in India are feared to be hit very badly. The implementation of WTO recommendations at macro level since 1991 has led to the development of Malls across length and breadth of the country. The recent decision, however, is likely to create a different set of imperatives for retail industry in India. This study attempts to address this concern though from a different perspective. The purpose is to assess the likely impact which malls have on the unorganised retail neighbourhood in their respective catchment areas within the vicinity of 200-500 meters distance.

The evidence on the impact of malls on unorganised retail is contrasting with some studies showing impressive and favourable impact of malls on the small shopkeepers. However, there is a strong evidence substantiating the claim that shopping malls have a detrimental impact on unorganised retail outlets.

\section{Literature Review}

The review of literature shows that the emergence of shopping malls has severely influenced operations of small shopkeepers and other unorganised business outlets. The sales figures and operating profits have been shown to be badly experiencing a receding behaviour. A study on the "impact of malls on small shops and hawkers in Mumbai" (Kalhan, 2007) unambiguously indicated that there has been a severe impact of malls on the unorganised retail shops operating in the vicinity of malls. The study further stated that Mega Malls are making deep inroads in the sales of retailers operating in the unorganised retail sector.

A study on the "Impact of shopping malls on the unorganised retail sector - a case study of Mangalore region" stated that the malls interestingly have no severe impact on the employment scenario. However, the study further revealed that Malls have severely impacted the Turnover and Operating profits of the sample shops. Besides, there is also an adverse impact on the customers of sample shops. A survey based study of small unorganised retailers operating in close proximity to Food World and Subhiksha( CII-KSA Technologies) in Chennai showed that none of them had to close their operations with the advent of these big organised retail formats. The study observed that there was a little impact on the sales and inventory on the selected respondents in the initial period of time; however, it changed gradually.

Mukherjee and Patel, 2005, carried out a broad based survey on "FDI in the Retail Sector in India", which was sponsored by the Indian Council for Research on International Economic Relations ( ICRIER), vehemently recommended the allowing of FDI in the organised format in retail industry over a period of five to six years to boost the speed at which the organised retail sector is growing. The study further bracketed not so severe impact on unorganised retail sector which could lead to their closure.A survey of 100 youths conducted 
by "The Hindu" revealed that the opening of super and hyper markets, cloth and accessory stores, eateries and multiplexes have thrown better choice and thrilling experience of Mangaloreans ( Nayak\&Suvarna, 2010) . A survey based research conducted revealed that the changing nature of demographic factors and improvement in the awareness level of consumers about various product related attributes like quality, now that the consumers' preferred to purchase different products both from the organised and unorganised retailers. Therefore, both the organised and unorganised retail outlets have to implement various value-added services to attract these customers ( Ramanathan\&Hari, 2011).

\section{Objectives of the Study}

The study was conducted with the following research objectives:

- To identify and outline the socio-economic profile of the selected unorganised retailers.

- To identify the impact of shopping malls on the sales and profits of the sample retailers.

- To study and explore the perception and attitudes of small retailers towards the Shopping Malls.

- To provide the suggestions and recommendations.

\section{Research Methodology}

The research design is descriptive and exploratory in nature. The former research design is characterised by that it describes the problem as it exists and the researcher has no control over the variables. The exploratory research design helps in getting a deeper insight into the problem. The sample size refers to the number of items to be selected from the universe to constitute the sample. A size of 200 small retailers was identified and selected for the study based on various attributes like shop size, type of goods and their shops being located in the defined zone of 200- 400 meters of distance from the shopping mall. The data collection was done with the help of a questionnaire crafted and administered with the purpose of eliciting the needed data for achieving the research objectives of the present study. The zone was created based on the proximity to the organised retail outlet with the purpose of identifying the severity of the impact on local shops. The data collection was done by conducting various on-site visits to the respondents.

The study was conducted in the Srinagar city of the state of Jammu and Kashmir. The city is witnessing a massive infrastructural development on various fronts. The peace and stability in the region has also attracted a lot of investment both from the local investors as well as the outside investment. The subsidy and other inducements from the state government has also given impetus to the development works in the city and organised retail sector being the biggest beneficiary. The Data analysis was done with the appropriate statistical techniques and tools like SPSS and Micro Soft Excel for sound interpretation.

IV. Analysis and Discussion Table: 1Demographic Profile of the respondents

$\mathbf{N}=\mathbf{2 0 0}$

\begin{tabular}{|c|c|c|}
\hline Attributes/category & No of Respondents & Percentage of Respondents \\
\hline a) Age $\quad$ & 20 & 10 \\
\hline Up to 25 years & 100 & 50 \\
\hline $26-35$ years & 60 & 30 \\
\hline 36-45 years & 20 & 10 \\
\hline Above 45 years & & 99 \\
\hline b) Gender $\quad 198$ & 1 \\
\hline Male & 2 & 35 \\
\hline Female & & 45 \\
\hline Education Status & 70 & 15 \\
\hline Primary & 90 & 5 \\
\hline Secondary & 30 & \\
\hline Graduation & 10 & \\
\hline Post-graduation & & \\
\hline
\end{tabular}

Source: Primary Data

The analysis of the table-1 shows that overwhelming majority of the respondents are male $99 \%$ and just $1 \%$ respondent is female. This is purely because of the religious influence of the Kashmiri society which discourages the female participation in the market particularly shop keeping. Besides, $45 \%$ respondents hold graduation degrees, $35 \%$ hold secondary $(10+2)$ qualification and meagre $5 \%$ are post-graduates. This is explained by the overall lower literacy rates in Jammu \& Kashmir particularly in Kashmir province. The literacy rates are below the national averages. Further, the analysis reveal that 50\% respondents are between 26-35 age 
group and just $10 \%$ of the respondents are above the age group of 45 years. Which again reflects that the overwhelming majority (90\%) are in the "baby boomer" category and can provide the " demographic dividend" to the state.

Table: 2 Distribution of respondent Shops by Floor Space.

$\mathbf{N}=\mathbf{2 0 0}$

\begin{tabular}{|c|c|c|}
\hline Floor Space ( Sq. Feet) & No. of Respondents & Percentage of Respondents \\
\hline Below 200 & 50 & 25 \\
\hline $200-300$ & 100 & 50 \\
\hline $400-500$ & 30 & 15 \\
\hline Above 500 & 20 & 10 \\
\hline
\end{tabular}

Source: Primary Data

The analysis of the Table: 2 shows that just a meagre $10 \%$ of the respondents have a floor space in excess of 500 Sq. Feet, $75 \%$ respondents have a floor space less than or up to 300 Sq. Feet, which gives us a clear indication that the majority of the retail outlets in the vicinity of malls are highly small in size, which can clearly lead to " Size diseconomies" for the small shop keepers and again has a possibility of hitting both the Top-line and Bottom-line of these un-organised retail outlets. The survey found that the un-organised retail outlets felt a strong urge in upgrading their floor space. The overwhelming response from the respondents was that the floor space acts as a big deterrent for them to remain competitive vis-à-vis organised retail formats, and even more so in the future.

Table: 3 Sales Turnover and Operating Profit behaviour of Unorganised Retail Outlets $\mathrm{N}=\mathbf{2 0 0}$

\begin{tabular}{|c|c|c|c|}
\hline Parameter & Increased & Same/Unchanged & Declined \\
\hline Profit & $60 \%$ & $15 \%$ & $25 \%$ \\
\hline Sales & $65 \%$ & $20 \%$ & $15 \%$ \\
\hline
\end{tabular}

Source: Primary Data

The Table: 3 throws some astonishing figures, than analysis reveal that a great majority of $60 \%$ respondents reported an increase in the profits after the opening of the organised retail formats like Malls, $15 \%$ reported status-quo in the profit behaviour. However, still a good percentage of respondents revealed a drop in their profit rates post-mall operation.

The analysis further revealed that $65 \%$ respondents reported a jump in their sales after the Malls have started to operate in their vicinity, $20 \%$ reported an unchanged behaviour of sales figures and $15 \%$ respondents reported a drop in their sales figures. This is in fact a classical example of what economists call "external economies effect" and the opening up of organised retail formats have led to the "localising" of customer foot fall rates and dissonance of buyers from the malls on account of various reasons have resulted into "Positive spill over" impact on the local small shop-keeper community. This is further, explained by the low per-capita income of the people. With low disposable incomes majority of folks barely afford to purchase it from organised retail formats. The survey also revealed that the non-availability of credit from the malls have also resulted in their immunity from adverse impact of organised retail format operations. $\mathbf{N}=\mathbf{2 0 0}$

Table: 4 Credit line offered by unorganised retail outlets Impacts behaviour of Sales and Profits

\begin{tabular}{|c|c|c|}
\hline Scale Option & No Of Respondents & Percentage Of \\
\hline Agree & 130 & 65 \\
\hline Can't Say & 35 & 17.5 \\
\hline Disagree & 35 & 17.5 \\
\hline
\end{tabular}

Source: Primary Data

The analysis of Table- 4 reveals the traditional nature of the buying behaviour of a typical Kashmir consumer. Traditionally small shopkeepers have been offering consumable and other items on credit. This has become a part of our bulk purchase which is purely necessities as the disposable income of a common Kashmiri as per data released by NSS is around Rs 45-47000 per annum which way below national average. We have abundant evidence from the organised retail format regarding their non-offering of merchandise on credit. This is a profound finding regarding the determinants of buying behaviour and consumer psychology of a typical Kashmiri consumer. 
Foreign Direct Investment and Unorganised Retail Sector - A Case Study.

$\mathbf{N}=\mathbf{2 0 0}$

Table: 5 Respondent Shops and impact on their loyal customers

\begin{tabular}{|c|c|c|}
\hline Result/Impact & No. Of Respondents & Percentage Of Respondents \\
\hline Increased & 120 & 60 \\
\hline Unchanged & 45 & 22.5 \\
\hline Declined & 35 & 17.5 \\
\hline
\end{tabular}

Source: Primary Data

The analysis of Table-5 revealed that a great majority of respondents $60 \%$ reported an increase in the patronage from their valued customers and opening of the organised retail formats have had a bare impact on the customer attrition. This is substantiated by the fact that only $17.5 \%$ respondents' shop keepers reported a decline in their loyal customer patronage. This finding is in consonance with the findings of above findings. This is partly explained by the minimal or moderate availability of value-added services by the organised retail. Besides, the sluggish promotion of the mix of product and service related benefits of the organised retail outlets.

Table: 6 Low Disposable Incomes have an Impact on Sales and Profits of unorganised retail outlets. $\mathbf{N}=\mathbf{2 0 0}$

\begin{tabular}{|c|c|c|}
\hline Scale Option & No Of Respondents & Percentage of Respondents \\
\hline Agree & 140 & 70 \\
\hline Can't Say & 30 & 15 \\
\hline Disagree & 30 & 15 \\
\hline
\end{tabular}

Source: Primary Data

The analysis of Table- 6 depicts that $70 \%$ of respondents think that the low disposable incomes results into their customer patronage either increasing or remaining same. This is primarily because the non-affordability of customers and high fixed prices set by the Malls. However, it reveals an interesting thing about the market dynamics in Kashmir. It remains to be seen that the respondent shopkeepers may be only getting the low income customers. But this thing gets repudiated by the increasing sales and profit behaviour of unorganised retail outlets. The respondents revealed that the high price branded merchandise by organised retail outlets has acted a blessing in disguise for the respondent shop keepers.

Table: 7 Attitudinal and Perceptual profile of the small retail outlets on the impact from organised retail formats.

$\mathbf{N}=\mathbf{2 0 0}$

\begin{tabular}{|c|c|c|c|}
\hline Survey Statements & Agree & Can't Say & Disagree \\
\hline Malls have a good impact on the small retail outlets & $\mathbf{6 5 \%}$ & $\mathbf{1 5 \%}$ & $\mathbf{2 0 \%}$ \\
\hline Govt. should promote FDI in retail & $\mathbf{6 9 \%}$ & $\mathbf{1 6 \%}$ & $\mathbf{1 5 \%}$ \\
\hline High value customers are switching over to organised Retail formats & $\mathbf{1 5 \%}$ & $\mathbf{1 0 \%}$ & $\mathbf{7 5 \%}$ \\
\hline Organised retail outlets sell merchandise at higher prices & $\mathbf{8 0 \%}$ & $\mathbf{5 \%}$ & $\mathbf{1 5 \%}$ \\
\hline Small shopkeepers favourably placed due to credit offering & $\mathbf{8 5 \%}$ & $\mathbf{7 \%}$ & $\mathbf{8 \%}$ \\
\hline Govt. provide them extra space for increasing the floor space & $\mathbf{6 8 \%}$ & $\mathbf{1 2 \%}$ & $\mathbf{2 0 \%}$ \\
\hline Malls provide good shopping experience due to add-on services & $\mathbf{5 0 \%}$ & $10 \%$ & $40 \%$ \\
\hline Malls have a dislodging potential for unorganised retail outlets & $\mathbf{6 5 \%}$ & $\mathbf{1 5 \%}$ & $\mathbf{2 0 \%}$ \\
\hline Low disposable income is favourable for organised retail outlets & $\mathbf{7 0 \%}$ & $\mathbf{1 0 \%}$ & $\mathbf{2 0 \%}$ \\
\hline Low exposure to organised retail is perpetuating unorganised retail patronage. & $\mathbf{6 0 \%}$ & $\mathbf{1 5 \%}$ & $\mathbf{2 5 \%}$ \\
\hline Customers are yet to grapple with the idea of hyper markets and Malls. & $\mathbf{6 8 \%}$ & $\mathbf{1 2 \%}$ & $\mathbf{2 0 \%}$ \\
\hline
\end{tabular}

Source: Primary Data

Tabe-7 reveals an astonishing mix of responses and provides a great amount of insight into the way unorganised retail outlets see the way organised giants impact or will impact them. In case of the close ended statement about whether the Govt. should promote FDI in retail a great majority of $69 \%$ favours this statement. Further, on the impact of malls on unorganised retail a great majority $65 \%$ feel that it has a good impact on the small shopkeepers. This basically explains the experience of the respondent sample shopkeepers which necessarily need not be true of other locations and areas. On the low exposure of Kashmiri consumers helping them in increasing their customer base or retaining the loyal customer patronage, again $60 \%$ of respondents favour this proposition while $20 \%$ disagree on this and $15 \%$ expressed indifference towards this statement.

\section{Findings of the Study}

- The male population dominates the unorganised retail industry in at least in the Srinagar area and the figure is $99 \%$ 
- Around $80 \%$ of the respondents hold primary and secondary qualification.

- The respondents in the age group of 25-45 dominate unorganised retail and this group constitutes around $90 \%$ of the sample size. This again shows that the male adults primarily rule the roost.

- The study also revealed that the Mall don't have any adverse impact on the sales and profitability of the respondent shopkeepers.

- There is also negligible adverse impact on the customer patronage of the unorganised retail outlets on account of the Malls.

- An overwhelming majority of the respondents observe that the entry of malls and permitting FDI in retail segment is not going to adversely impact the small unorganised retail industry in Srinagar city.

- The majority of the respondents also revealed that there is no need for them to upgrade their floor space.

- However, some value added services give a better shopping experience, this was revealed by good percentage of respondents.

\section{Limitations of the Study}

The major limitations of the presented study are given below:-

- The primary limitation is the uncontrollability of some variables like cultural impact on the buying behaviour of customers.

- There is possibility of sample respondent bias in their reporting of perceptual and attitudinal underpinnings on certain statements.

- There is a problem in generalising some findings as there are some unique variables at play.

- The sample size may also be an issue as it may not reflect the true behaviour of the universe.

- The study was conducted between October 2012-December 2012.

\section{Research Implication of the study}

The utility of this study is significant for all the stakeholders like retail outlets both organised and unorganised retail formats, Govt., academicians, policy makers and the society in general.

\section{Conclusion and Suggestions}

The study is a unique in that it has revealed some astonishing facts. The analysis of sample shops revealed that the malls and opening up of retail sector is not going to impact unorganised retail in a bad way. In contrast to the common belief, that Malls have an adverse impact on the unorganised retail segment, the study found quite an encouraging support for opening of the retail segment in at least in Srinagar city. This can be observed from the increasing sales, profits and customer base of unorganised small shopkeepers which fall in the vicinity of organised retail formats like Malls. The present study is just a humble attempt to unravel the mystery behind the impact of organised retail formats like supermarkets, malls etc. on the small shopkeepers. The findings of the present study are encouraging in that the policy makers can make certain policy changes in the context of retail segment in Kashmir. However, the implementation of theCentral governments' decision on FDI in Retail should be carried out in a controlled and phased mannerfor better reflecting the demands of all the stakeholders involved.

\section{References}

[1] Ajaz Ahmad and Suresh Mayya (2012). "Impact of Shopping Malls on the Unorganised Retail Sector: A Case Study of Mangalore Region, Indian Journal of Marketing, September 2012, p.31-40.

[2] CII-KSA, Technopark Report (2003). "Modernizing Retail In India." http://economictimes.indiatimes.com/articleshow/msid, accessed on Dec 25, 2012.

[3] Dale, A.R and Biswas R., (2007). "The Evolving Retail Market in India: Tremendous Opportunities Ahead." http://www.retailasiaonline.com/,acessed on January, 3, 2013.

[4] Kalirajan and Kanhaiya (2009). “ The Impact of Globalisation on Employment and Poverty Reduction In India: The Case of Emerging Big Shopping Malls and Retailers.

[5] KaushalShailesh.K, and Medhavi, S. (2011). "To Identify The prominent Factors of Shopping Mall Behaviour: A Factor Analysis Approach." Indian Journal Of Marketing, Volume 41, Issue 5, Page 53.

[6] Kotler Philip and Armstrong Gary (2008). "Principles of Marketing" $12^{\text {th }}$ Edition, New Delhi: Tata MacGraw Hill Publishing Company Limited.

[7] Kulveen T. “ The Rise of New Media And Product Promotion: Exploring The Potential Of Online Media In Advertising The Services Provided By Major Telecommunications Service Providers In India,Indian Journal Of Marketing, September, 2012.

[8] Levy Michael, Weitz Barton A.(2011). "Retail Management.” $8^{\text {th }}$ Edition, New Delhi: Tata MacGraw-Hill Publishing Company Limited.

[9] Mukherjee A. \& Patel N. (2005). “ FDI in Retail Sector India.” Academic Foundation- ICRIER Publications, New Delhi, pp 120123.

[10] NayakArchana\&Suvarna Nikhil. “ Brand Loyalty Strong Among Youth.” The Hindu, November 9, 2010,p.13. 